\title{
EFEKTIVITAS METODE PEMBELAJARAN DENGAN PENDEKATAN TUTORIAL DAN MINI GROUP DISCUSSION PADA KEGIATAN POSAKA (POS SIAGA KELUARGA) DI KECAMATAN SINGOSARI KABUPATEN MALANG
}

\author{
EFFECTIVENESS OF LEARNING METHOD WITH TUTORIAL AND MINI GROUP \\ DISCUSSION APPROACHES IN POSAKA ACTIVITIES (POS SIAGA FAMILY) IN \\ SINGOSARI - MALANG
}

\author{
Nurma Afiani', Misbahul Subhi ${ }^{2}$ \\ ${ }^{1}$ STIKES Widyagama Husada / Prodi S1 Ilmu Keperawatan, Malang \\ ${ }^{2}$ STIKES Widyagama Husada/ Prodi S1 Kesehatan Lingkungan, Malang
}

Alamat Korespondensi : Jl. Taman Borobudur Indah 3A Malang, Telp. (0341) 406150/ Fax (0341) 471277

E-mail: ${ }^{1)}$ nurmaafiani@widyagamahusada.ac.id, ${ }^{2)}$ misbahulsubhi@widyagamahusada.ac.id

\begin{abstract}
Current situation analyzes were conducted on social, cultural, religious, health, service quality and social life aspects. The results of the situation analysis indicate that the problems are: the decrease of the spirit of gotong royong to the local community, the lack of fiber and vegetable consumption, and the consumption of fast food becomes habit. The aim of this program is to identify the effectiveness of learning method with tutorial and mini group discussion approach to improve knowledge and skill in first aid (P3K) and plant technique in limited field with hydroponic technique for security officers and youth group at RW 12 and $R W 15$ Desa Watugede.

Quasi-experiment with pre-post-test design without control group. The statistical test used is paired t-test, with 45 respondents. Knowledge and skills of the participants after training increased ( $p$-value <0.005), Knowledge before $(n=45)$, Mean $=60$ (40-90), Knowledge after $(n=45)$, Mean $=80$ (70-100). Teaching methods with tutorial and mini group discussion approaches are effective to improve knowledge and skills in first aid and planting techniques in limited field with hydroponic techniques on security officers and youth group at $R W 12$ and RW 15 Desa Watugede.
\end{abstract}

Keywords: Hydroponic, P3K (First Aid Training), Pos Siaga Keluarga (POSAKA) 


\begin{abstract}
ABSTRAK
Analisa situasi terkini dilakukan pada kedua lokasi mencakup aspek sosial, budaya, religi, kesehatan, mutu layanan dan kehidupan bermasyarakat. Hasil analisa situasi menyebutkan bahwa masalah yang ada pada kedua kelompok masyarakat sejenis yakni: menurunnya semangat gotong royong pada masyarakat setempat, kurangnya konsumsi serat dan sayuran, pola konsumsi fast food menjadi kebiasaan, peran poskamling kurang optimal, lahan TOGA tidak terawat, tidak memiliki lahan untuk menanam sayur dan buah secara mandiri, bencana longsor, rumah roboh, serta rawan tindak kriminalitas. Tujuan program ini mengetahui efektivitas metode pembelajaran dengan pendekatan tutorial dan mini group discussion untuk meningkatkan pengetahuan dan keterampilan dalam P3K dan teknik menanam dilahan terbatas dengan teknik hidroponik pada petugas keamanan dan remaja karang taruna di RW 12 dan RW 15 Desa Watugede.

Metode penelitian yang digunakan adalah Quasi-eksperiment dengan pre-post-test desain tanpa kelompok kontrol. Uji statistik yang digunakan yakni t-test berpasangan, dengan 45 responden. Hasil penelitian menunjukan bahwa rata-rata pengetahuan dan keterampilan peserta setelah pelatihan meningkat ( $\mathrm{p}$-value $<0,005)$. Pengetahuan sebelum $(n=45)$, Mean=60 (40-90), Pengetahuan sesudah $(\mathrm{n}=45)$, Mean=80 (70-100). Metode pembelajaran dengan pendekatan tutorial dan mini group discussion efektif untuk meningkatkan pengetahuan dan keterampilan dalam P3K dan teknik menanam dilahan terbatas dengan teknik hidroponik pada petugas keamanan dan remaja karang taruna di RW 12 dan RW 15 Desa Watugede.
\end{abstract}

\title{
Kata Kunci : Hidroponik, P3K (Pertolongan Pertama pada Kecelakaan), Pos Siaga Keluarga (POSAKA).
}

\section{PENDAHULUAN}

Lokasi penelitian ini berada di dua wilayah yakni RW 15 dan RW 12 Dusun Boro Desa Watugede. Kedua lokasi tersebut merupakan bagian dari Kecamatan Singosari yang termasuk dalam wilayah Kabupaten Malang Provinsi Jawa Timur. RW 15 Kelurahan Watugede dan RW 12 Desa Watugede merupakan sebuah area perumahan Masyarakat Berpenghasilan Rendah (MBR) bersubsidi yang dikembangkan oleh Kementerian Perumahan Rakyat (Kemenpera) sejak tahun 2007. Perumahan yang lebih sering disebut sebagai Perum Bumi Mondoroko Raya (BMR) ini terdiri lebih dari 5.000 unit rumah sederhana dan dihuni lebih dari 20.000 jiwa [2]. Mayoritas penduduk merupakan pendatang dari berbagai kota di Indonesia yang memiliki mata pencaharian di Kota Malang dan sekitarnya. Padatnya penduduk di area perumahan ini dapat berpotensi positif jika mampu dikelola dengan baik.

Masyarakat dilokasi tersebut memiliki karakter masyarakat pekerja dengan keterbatasan waktu dalam kegiatan sosialisasi. Keterbatasan waktu tersebut mempengaruhi pola kehidupan sehari-hari masyarakat termasuk pola konsumsi harian. Serba instant dan cepat saji menjadi gaya hidup yang dilakukan oleh masyarakat. Hasil studi pendahuluan menunjukkan bahwa masyarakat mitra hanya sebagian kecil yang memasak makanan sendiri setiap harinya, beberapa alasan umum yang dikemukakan antara lain: tidak memiliki waktu untuk berbelanja, sulit mendapatkan bahan mentah sesuai keinginan, dll. Kelompok ibu-ibu yang tergabung dalam kegiatan PKK mencoba untuk mengembangkan kebun penghasil sayuran namun terkendala keterbatasan waktu pengelolaan dan lahan tanam. Keterbatasan waktu dalam merawat tanaman TOGA tersebut menjadi kendala utama bagi ibuibu PKK diwilayah tersebut. Lokasi taman TOGA yang jauh dari area pemukiman juga menjadi salah satu faktor penyebab tidak terawatnya tanaman tersebut.

Lokasi penelitian berada diarea tanah yang berkontur perbukitan dan tebing yang diapit oleh dua sungai besar sehingga menimbulkan berbagai resiko bahaya. Pihak pengembang (developer) melakukan beberapa upaya pelebaran dan perataan area 
tepian sungai dan tebing dalam upaya untuk menambah jumlah unit hunian. Proses pembangunan unit hunian dilakukan dalam waktu singkat setelah proses perataan. Kurangnya kepadatan tanah disertai dengan curah hujan yang tinggi membuat beberapa area mengalami longsor sehingga unit hunian yang dibangun runtuh. Bencana longsor pernah terjadi dibeberapa titik baik di RW 15 maupun RW 12 diantaranya: Blok GJ mengalami rumah roboh beberapa saat setelah dibangun, perbukitan area pemakaman masyarakat Tionghoa, area jalan umum Blok GG perumahan yang berlokasi tepat ditebing sungai, rumah warga Blok GI mengalami longsor. Beberapa kasus tersebut menunjukkan bahwa beberapa titik diarea mitra beresiko mengalami bencana longsor.

Frekuensi kejadian tanah longsor pada titik-titik tertentu mencapai 5 kali selama satu tahun terakhir (2015-2016). Tanah longsor terjadi terutama pada musim penghujan. Lokasi perbukitan yang digunakan sebagai areal pemakaman etnis Tionghoa menjadi lokasi yang paling sering mengalami tanah longsor. Lokasi pemakaman berada sekitar 10 meter tepat diatas akses jalan lajur kiri utama masuk perumahan. Longsor diarea tersebut pernah terjadi beberapa kali saat hujan deras disertai angin kencang, beberapa pohon tumbang disertai dengan longsornya tanah. Akses masuk menuju perumahan sempat terganggu akibat adanya tumpukan tanah dan pohon tumpang namun untungnya tidak terdapat korban jiwa dalam kejadian ini. Tebing sungai pada RW 15 juga menjadi salah satu area yang mengalami longsor paling luas jika dibandingkan area lainnya. Pada lokasi ini pernah terjadi longsor yang membuat hampir sekitar area jalan berdiameter 5meter ambles masuk kesungai Kondisi seperti ini membuat masyarakat merasa cemas saat curah hujan tinggi disertai angin kencang akibat adanya resiko tanah longsor.

Kenyamanan, keamanan, dan ketertiban merupakan komponen penting dalam kehidupan masyarakat. Situasi dan kondisi yang kondusif menjadi jaminan terselenggaranya pembangunan serta kegiatan kemasyarakatan lainnya. Kondisi kedua mitra secara umum relatif aman, tertib dan terkendali. Masyarakat mitra jauh dari permasalahan yang mengarah pada tindak kriminal/ konflik yang ada. Meski tidak pernah terjadi konflik berat pada mitra, namun tindak kriminalitas berupa pencurian masih sering terjadi. Area pemukiman mitra belum menggunakan one gate system sehingga sulit dilakukan pemantauan dan berpotensi menimbulkan situasi yang kurang kondusif. Kontrol keamanan masih sulit dilakukan pada area mitra akibat beberapa hal, belum adanya Pos Kamling (Pos keamanan Lingkungan) sesuai standar, belum optimalnya peran dan fungsi Pos Kamling, serta belum adanya petugas keamanan khusus.

Siskamling (Sistem Keamanan Lingkungan) bertujuan untuk menciptakan situasi dan kondisi yang aman, tertib dan tentram di lingkungan masing-masing [3]. Peraturan Kapolri tersebut juga menyebutkan bahwa siskamling memiliki 9 tanggung jawab penting antara lain: penjagaan; patroli; peringatan tentang adanya bahaya kejahatan, bencana alam, dll; memberikan informasi tentang keamanan; membantu menyelesaikan masalah, berkoordinasi dengan Polri; melakukan tindakan represif serta melakukan tindakan keselamatan bagi warga yang memerlukan. Secara keseluruhan kedua mitra telah memiliki Poskamling secara fisik, namun sayangnya peran dan fungsi Poskamling tersebut belum tampak nyata. Terlebih dengan adanya potensi bencana alam maupun bencana akibat ulah manusia dilokasi mitra maka kesiapan Poskamling setempat dirasa masih kurang. Poskamling kedua mitra dimana secara fisik bangunan cukup baik namun tidak ada perlengkapan maupun petugas penunjang fungsi Poskamling.

Deskripsi analisa situasi diatas menggambarkan bahwa masyarakat umum RW 12 dan RW 15 Desa Watugede memiliki permasalahan yang cukup kompleks. Ringkasan permasalahan khusus yang dialami oleh mitra antara lain: konsumsi sayur kurang, lahan TOGA tidak 
dikelola dengan baik, potensi longsor terkait dengan kondisi topografi area, dan sistem keamanan lingkungan belum berfungsi secara optimal. Demikian hasil analisa situasi yang dilakukan dengan memadukan antara data primer, data sekunder, hasil wawancara dengan pihak terkait dan observasi kondisi secara langsung.

\section{TUJUAN DAN METODE}

$\begin{array}{llr}\text { Tujuan } & \text { penelitian ini } & \text { adalah } \\ \text { mengetahui } & \text { efektivitas } & \text { metode } \\ \text { pembelajaran dengan pendekatan } & \text { tutorial } \\ \text { dan mini group discussion untuk } & \text { mentahuan dan } \\ \text { meningkatkan } & \text { pengetahuan }\end{array}$ keterampilan dalam P3K dan teknik menanam dilahan terbatas dengan teknik hidroponik pada petugas keamanan dan remaja karang taruna di RW 12 dan RW 15 Desa Watugede.

Metode yang digunakan yakni quasieksperiment dengan pre-post-test desain tanpa kelompok kontrol. Uji statistik yang digunakan yakni $t$-test berpasangan. Jumlah sampel yang digunakan ditetapkan berdasarkan teknik total sampling, dimana seluruh petugas keamanan dan remaja karang taruna menjadi responden dalam penelitian ini $(n=60)$.

\section{HASIL DAN PEMBAHASAN}

Pada bagian berikut ini akan disajikan hasil kegiatan yang telah dilakukan untuk meningkatkan pengetahuan dan keterampilan dalam P3K dan teknik menanam dilahan terbatas dengan teknik hidroponik pada petugas keamanan dan remaja karang taruna di RW 12 dan RW 15 Desa Watugede.

\section{Hasil Kegiatan Pos Siaga Keluarga (POSAKA)}

Kegiatan Posaka ini dilakukan melalui beberapa tahapan utama yakni: persiapan, pelaksanaan dan evaluasi. Berikut ini merupakan hasil kegiatan yang telah dilakukan tim pengusul bersama mitra dalam setiap tahapnya:

\section{a. Tahap Persiapan}

Tahap persiapan oleh tim dilakukan melalui koordinasi internal tim. Proses koordinasi internal tim dilakukan beberapa kali dimana fokus kegiatan adalah pada pembagian jobdescription masingmasing anggota, pembahasan teknis kegiatan serta diskusi terkait media pembelajaran yang akan digunakan (modul, SOP, video, dll). Hasil diskusi tim menyepakati bahwa materi pelatihan P3K akan diberikan oleh ketua tim, dengan mahasiswa sebagai fasilitator. Sedangkan pelatihan teknik menanam dilahan sempit akan dilakukan oleh anggota tim bersama pakar dari Balai Pembibitan dan Pengkajian Dinas Pertanian Kabupaten Malang.

Berkas kegiatan yang disiapkan oleh tim antara lain: formulir pendaftaran peserta pelatihan, lembar identitas peserta pelatihan, materi pelatihan, pelatihan kit, absensi peserta, berita acara kegiatan, sertifikat bagi fasilitator kegiatan, undangan bagi tokoh masyarakat, undangan bagi peserta, dan lain-lain. Persiapan tempat kegiatan serta sarana prasarana penunjang dilakukan bersama mitra. Hasil koordinasi menyepakati bahwa kegiatan akan diselenggarakan di gudang perumahan yang bertempat di area RW 15 Dusun Boro Desa Watugede Kecamatan Singosari Kabupaten Malang.

Tim bekerja sama dalam mempersiapkan sarana prasarana penunjang kegiatan. Sound system, microphone, kabel listrik disiapkan secara swadaya oleh warga setempat, sedangkan layar proyektor dan LCD disiapkan oleh tim. Tim juga menyiapkan alat dan bahan peraga pertolongan pertama pada kondisi gawat darurat seperti phantom bantuan hidup dasar, bebat elastic bandage, bidai, cairan pembersih luka, kassa, relawan yang di make up sebagai korban, sarung tangan, masker serta 
berbagai obat luar untuk rawat luka. Untuk pelatihan hidroponik alat dan bahan disiapkan oleh tim bersama tim dari Balai Pengkajian Teknologi Pertanian Jawa Timur.

\section{b. Tahap Pelaksanaan}

Kegiatan Posaka (Pos Siaga Keluarga) dilakukan melalui beberapa rangkaian kegiatan inti. Upaya mewujudkan masyarakat tangguh dilakukan melalui beberapa pelatihan yakni: pelatihan pertolongan pertama pada kondisi gawat darurat dan pelatihan teknik menanam di lahan terbatas dengan metode hidroponik. Berikut ini merupakan target capaian yang diharapkan pada tahap pelaksanaan: (1) Meningkatkan pengetahuan dan keterampilan petugas keamanan setempat dalam pertolongan pertama (P3K) dilingkungan rumah warga; (2) Meningkatkan pengetahuan dan keterampilan petugas keamanan setempat dalam kesiapsiagaan terhadap bencana; (3) Meningkatkan pengetahuan dan keterampilan ibu-ibu warga setempat dalam bercocok tanam dilahan sempit dengan teknik hidroponik; (4) Membantu meningkatkan sarana prasarana standart yang wajib terdapat pada pos keamanan lingkungan (Poskamling); (5) Mewujudkan pos keamanan lingkungan (Poskamling) sebagai pos siaga keluarga (POSAKA).

Pelatihan pertolongan pertama pada kondisi gawat darurat dan pelatihan teknik menanam di lahan terbatas dengan metode hidroponik dilaksanakan di Gudang Perumahan Perum Bumi Mondoroko Raya Blok GL. Total jumlah target peserta pelatihan dari RW 15 dan RW 12 untuk pertolongan pertama pada gawat darurat adalah 30 orang dan peserta pelatihan hidroponik adalah 30 orang. Hasil evaluasi kegiatan menunjukkan bahwa total peserta hadir berjumlah $80 \%$ dan mayoritas berasal dari RW 15. Pelatihan juga dihadiri oleh tokoh masyarakat setempat antara lain Bapak Ketua RW 12, Bapak wakil ketua RW 15, Pembina Karang Taruna RW 15 serta tim koordinator keamanan. Pelatihan hidroponik didukung oleh tim pemateri dari penyuluh Balai Pengkajian Teknologi Pertanian Jawa Timur. Materi utama yang disampaikan dalam kegiatan pelatihan kader ini adalah: teknik pertolongan pertama pada kondisi gawat darurat, teknik evakuasi diri pada kondisi bencana serta teknik bercocok tanam dengan hidroponik.

Peserta yang telah melakukan registrasi akan mendapatkan pelatihan kit, formulir data diri, lembar pre-test serta snack. Pada sesi materi pelatihan $\mathrm{P} 3 \mathrm{~K}$ peserta mendapatkan penjelasan mengenai konsep POSAKA secara ringkas, teknik evakuasi diri dalam kondisi bencana, materi pertolongan pertama pada kondisi gawat darurat seperti luka terbuka dengan perdarahan hebat, tatalaksana awal patah tulang, dan teknik bantuan hidup dasar pada korban henti jantung. Peserta diperkenankan mengajukan pertanyaan jika selama proses penyampaian materi dirasa terdapat hal-hal yang kurang dipahami. Demo teknik pertolongan pertama juga dilakukan bersamaan dengan penyampaian materi untuk memberikan gambaran secara menyeluruh kepada peserta.

Sesi penyampaian materi dilanjutkan dengan pembagian peserta dalam kelompok kelompok kecil. Setiap kelompok kecil terdiri atas 4-5 orang peserta dan didampingi oleh 1 orang mahasiswa sebagai fasilitator. Metode pembelajaran mini group discussion dalam pelatihan ini diharapkan mampu meningkatkan pemahaman peserta terhadap materi serta memfasilitasi masing-masing individu dalam mempraktekkan 
keterampilan yang telah diperoleh. Kegiatan dalam kelompok kecil akan diawali dengan review materi oleh fasilitator, dilanjutkan dengan diskusi dan tanya jawab untuk menggali pemahaman peserta. Fasilitator akan memberikan kesempatan masing-masing peserta untuk mempraktekkan keterampilan yang telah dipelajari. Setelah peserta mempraktekkan keterampilan tertentu maka fasilitator akan memberi kesempatan peserta lain untuk memberikan feedback.

\section{c. Tahap Evaluasi}

Tim melakukan evaluasi paska kegiatan pelatihan mencakup jumlah kehadiran peserta, keaktifan peserta, hasil pre-test dan post-test. Berikut ini merupakan ringkasan hasil evaluasi selama proses pelatihan berlangsung:

1) Ketercapaian target jumlah peserta pelatihan pada kedua mitra terdapat perbedaan yang bermakna. Mitra pertama yakni RW 15 kehadiran peserta pelatihan mencapai $100 \%$, sedangkan mitra kedua yakni RW 12 kehadiran peserta kurang dari 50\%. Jumlah peserta hadir total adalah 48 orang (3 orang drop-out akibat ijin pulang terlebih dahulu);

2) Peserta kegiatan pelatihan aktif mengikuti proses penyampaian materi, demonstrasi keterampilan hingga praktik dalam kelompok-kelompok kecil. Selama penyampaian materi peserta aktif menyimak dan mengajukan pertanyaan, catatan notulensi menunjukkan bahwa 6 peserta mengajukan pertanyaan selama materi $\mathrm{P} 3 \mathrm{~K}$ dan 3 peserta mengajukan pertanyaan selama materi hidroponik;

3) Hasil pre-test dan post-test menunjukkan bahwa rata-rata pengetahuan warga terhadap materi pelatihan yang diberikan meningkat. Tabel berikut ini menunjukkan hasil uji-T berpasangan tingkat pengetahuan sebelum dan sesudah pemberian materi pelatihan.

Tabel 3.1 Uji T-Berpasangan Tingkat Pengetahuan Warga Sebelum dan Setelah Pelatihan Pos Siaga Keluarga

\begin{tabular}{cccccc}
\hline Variabel & n & Mean & Min & Mak & p-value \\
\hline Pengetahuan Sebelum & 45 & 60 & 40 & 90 & \multirow{2}{*}{$<0,005$} \\
Pengetahuan Sesudah & 45 & 80 & 70 & 100 & \\
\hline
\end{tabular}

\section{Pembahasan Indikator Capaian Kegiatan}

Indikator keberhasilan kegiatan POSAKA didasarkan atas terselesaikannya prioritas permasalahan yang telah disepakati. Prioritas permasalahan yang disepakati bersama mitra yakni peningkatan peran dan fungsi Poskamling sebagai Pos Siaga Keluarga (POSAKA), serta peningkatan kemampuan warga untuk menghasilkan tanaman buah dan sayur dilahan sempit (Hidroponik). Prioritas permasalahan tersebut di-breakdown kembali oleh tim dengan menentukan tujuan khusus dan langkah-langkah solutif nyata yang dilakukan bersama kedua mitra. Untuk lebih memudahkan dalam menilai keberhasilan kegiatan maka tim meninjau sejauh mana tim bersama mitra telah mencapai target yang diharapkan. 
Tabel 3.2 Identifikasi Ketercapaian Target Kegiatan POSAKA

\begin{tabular}{|c|c|c|c|}
\hline No & Tujuan Khusus POSAKA & $\begin{array}{c}\text { Kegiatan yang telah } \\
\text { dilakukan }\end{array}$ & $\begin{array}{c}\text { Analisis } \\
\text { Ketercapaian }\end{array}$ \\
\hline 1. & $\begin{array}{l}\text { Meningkatkan pengetahuan dan } \\
\text { keterampilan petugas keamanan } \\
\text { setempat dalam pertolongan } \\
\text { pertama (P3K) dilingkungan rumah } \\
\text { warga }\end{array}$ & $\begin{array}{l}\text { Pelatihan P3K dengan materi: } \\
\text { - Teknik pemeriksaan awal } \\
\text { - Teknik menghentikan } \\
\text { perdarahan hebat } \\
\text { - Teknik tatalaksana awal patah } \\
\text { tulang } \\
\text { - Teknik bantuan hidup dasar } \\
\text { - Teknik mengeluarkan benda } \\
\text { asing (tersedak) }\end{array}$ & $\begin{array}{l}\text { Kegiatan sudah } \\
\text { dilakukan } 100 \% \\
\text { dengan evaluasi rata- } \\
\text { rata pengetahuan dan } \\
\text { keterampilan peserta } \\
\text { setelah pelatihan } \\
\text { meningkat } \quad(p- \\
\text { value }<0,005)\end{array}$ \\
\hline 2. & $\begin{array}{l}\text { Meningkatkan pengetahuan dan } \\
\text { keterampilan petugas keamanan } \\
\text { setempat dalam kesiapsiagaan } \\
\text { terhadap bencana }\end{array}$ & $\begin{array}{l}\text { Pelatihan evakuasi diri dgn } \\
\text { materi: } \\
\text { - Evakuasi diri saat gempa } \\
\text { - Evakuasi diri saat kebakaran } \\
\text { - Evakuasi diri saat tanah } \\
\text { longsor }\end{array}$ & $\begin{array}{l}\text { Kegiatan sudah } \\
\text { dilakukan } 100 \% \\
\text { dengan evaluasi rata- } \\
\text { rata pengetahuan dan } \\
\text { keterampilan peserta } \\
\text { setelah pelatihan } \\
\text { meningkat }(p- \\
\text { value }<0,005)\end{array}$ \\
\hline 3. & $\begin{array}{lcc}\text { Meningkatkan } & \text { pengetahuan dan } \\
\text { keterampilan ibu-ibu } & \text { warga } \\
\text { setempat dalam } & \text { bercocok } & \text { tanam } \\
\text { dilahan sempit dengan } & \text { teknik } \\
\text { hidroponik } & & \end{array}$ & $\begin{array}{l}\text { Pelatihan hidroponik dgn materi: } \\
\text { - Definisi hidroponik } \\
\text { - Alat dan bahan hidroponik } \\
\text { - Cara perawatan hidroponik } \\
\text { - Praktik merangkai set alat } \\
\text { hidroponik } \\
\text { - Praktik menanam dg teknik } \\
\text { hidroponik }\end{array}$ & $\begin{array}{l}\text { Kegiatan sudah } \\
\text { dilakukan } 100 \% \\
\text { dengan evaluasi rata- } \\
\text { rata pengetahuan dan } \\
\text { keterampilan peserta } \\
\text { setelah pelatihan } \\
\text { meningkat } \\
\text { value }<0,005)\end{array}$ \\
\hline
\end{tabular}

\section{KESIMPULAN}

Metode pembelajaran dengan pendekatan tutorial dan mini group discussion efektif untuk meningkatkan pengetahuan dan keterampilan dalam P3K dan teknik menanam dilahan terbatas dengan teknik hidroponik pada petugas keamanan dan remaja karang taruna di RW 12 dan RW 15 Desa Watugede.

\section{DAFTAR PUSTAKA}

Badan Perumahan Kabupaten Malang. (2012). Program Kemenpera Perumahan Masyarakat Berpenghasilan Rendah (MBR).

Dahlah, Sopiyudin. (2011). Statistika Untuk Kesehatan. Salemba Medika: Jakarta.

Peraturan Kapolri. (2007). Peraturan Kapolri No. 23 Tentang Sistem Keamanan Lingkungan. RW 15. (2016). Data Warga Perumahan Bumi Mondoroko Raya Tahun 2016. 
JURNAL ILMIAH KESEHATAN MEDIAHUSADA | VOLUME 07/NOMOR 01/MARET 2018 